nom daglige notater som hun tok. Hun møter to kulturer.

Den ene er de gamle pasientene. De fleste av dem bor i store leiligheter som preges av fordums prakt, med fine gamle møbler, praktfulle malerier, tepper og kunst. De er ofte meget gamle og med mange og ofte alvorlige sykdommer og får inntil tre ganger daglig besøk fra hjemmesykepleien. Flesteparten er kvinner, og de har mistet sine nærmeste. To fellestrekk skiller seg ut: Det ene er at de er ensomme, for «alle deres er døde». De har slektninger, arvinger, men de er travelt opptatt med sitt. Derfor er ensomheten ofte overveldende og ødeleggende. Humoren har nok noen beholdt. En klappet seg på sitt hvite hode og sa om seksuallysten: «Det kan jo være fyr på peisen, selv om det er sne på taket!» Det andre trekket er at de ønsker å dø hjemme i sin egen seng, i fred og verdighet. De er livende redde for sykehus og sykehjem. Forfatteren opplever at ensomheten er det overveldende fellestrekket.

Den andre kulturen er hjemmesykepleien. Pleierne, bare kvinner, løper fra jobb til jobb. Listene deres er for lengst sprengt, men likevel kommer det stadige tillegg, fordi både de gamle og pleierne blir syke. Pleierne sykmelder seg fordi de er utslitt, selv om de vet at det går utover de andre, for de orker ikke mer. De løper etter stoppeklokkene og forsøker å klare de oppdragene administrasjonen har ført opp. Det er aldri tid til å sette seg ned, ta en kopp kaffe og snakke med de gamle. De må forholde seg til listene, de overfylte skittentøyskurvene og de stinkende søplebøttene.

Oppe i alt dette møter forfatteren Felicia, en gammel skrøpelig og kreftsyk dame på listen. Hun fortalte om den overveldende kjærligheten hun hadde opplevd med sin mann. De hadde bodd i flere år i Rom, og nå var mannen død. Hun bar på en siste drøm, og det var en tur til Rom for å gjenoppleve kjærligheten. Forfatteren ble med henne på en ukes tur til Roma, trillet henne omkring i rullestolen. Og Felicia gjenopplevde kjærligheten. Så dro de hjem, og neste morgen lå Felicia død i sengen sin etter å ha tatt en stor overdose sovemiddel. Forfatteren følte at Felicia hadde et lykkelig og takknemlig smil der hun lå.

Forfatteren skriver godt, ofte glitrende godt. Alle de små historiene om pasientene og pleierne er stor forfatterkunst. Mange i vårt samfunn ville ha glede av å lese denne boken og tenke over hvordan det er blitt og hva vi kan gjøre med det. Spesielt gjelder det selvfølgelig fastlegene og personalet i eldreomsorgen. Men aller mest gjelder det politikerne og byråkratene som har ansvaret for samfunnet og den veien vi går. Jeg håper boken får mange lesere.

\section{På dypt vann}

Jacobsen S

Passasjeren

317 s. Oslo: Aschehoug, 2009. Pris NOK 349 ISBN 978-82-03-21173-7

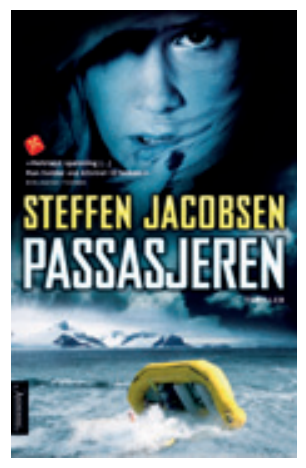

Den danske legen Steffen Jacobsen debuterte i 2008 (på norsk i 2009) som krimforfatter med boken Passasjeren. Handlingen er lagt til Sjælland og Bjørnøya, med avstikkere til Tromsø.

Vi møter den suksessrike forretningsmannen og milliardæren Axel Nobel og hans venn Jacob Nelleman. Sistnevnte drepes med pil og bue under en jakt på Nobels gods. Tilsynelatende en jaktulykke, men leseren vet nokså umiddelbart at dette er et mord.

Vi aner underliggende konflikter, og det fremgår at utspringet for disse er et forlis ved Bjørnøya et år tidligere, der Nobel og Nellemann var på seiltur sammen med den vakre unge kvinnen Anne Bjerke. Nobel og Nellemann reddet seg selv, men etterlot den skadede og døende Anne Bjerke. Anne ble aldri funnet. Etterforskningen avslører tidlig at Annes bror Jonas, en habil bueskytter, tilsynelatende har gjemt drapsvåpenet i sin egen garasje. At løsningen ikke er så enkel, forstår vi idet vi introduseres for en navnløs, ukjent person som hele tiden er på høyde med etterforskningen.

Deltidsarbeidende spillentusiast Robin Hansen er bokens politietterforsker. I krimlitteraturens brokete forsamling av bisarre etterforskere med outrert livsførsel og havarert privatliv, er han et sympatisk og oppfriskende bekjentskap. Hans overordnede Philipsen er langt mer karikert.

Den første halvdelen har en relativt slakk spenningskurve. Jacobsen er kunnskapsrik og har tendens til lange utredninger og blir i perioder noe doserende. Spesielt gjelder det seiling og båtlivets mange finesser, der en som aldri har satt sin fot $i$ en seilbåt fort blir hektet av og tar lesepause. Likevel, når det er sagt, begeistrer likevel Jacobsen. Han behersker det som tross alt er viktigst, nemlig språket. Han har grep om dialogene, snert i formuleringene, og hans evne til å tegne flerdimensjonale karakterer vitner om psykologisk innsikt. Dette til tross for at hans hang til bruk av similer, sammenlikninger, til tider blir noe påtrengende. I første del er også begrepet «som om» gjentatt påfallende hyppig, opptil tre ganger på en side. Jacobsen kommer likevel unna fordi han faktisk er både tørrvittig og uvanlig assosiasjonsrik.
Hvorvidt leseren tilfredsstilles, avhenger i stor grad av opprullingen. Her blir Jacobsen for langdryg. De lange naturbeskrivelsene og seilturens viderverdigheter blir for omstendelig og senker temperaturen $i$ avslutningen. Skurkens motiver for å drepe seks personer var for undertegnede heller ikke åpenbare.

Likevel vil jeg uten å nøle anbefale Passasjeren. Jeg vil utvilsomt også lese hans neste bok, i håp om at han da har karet seg i land og fortøyd båten.

Jorun Thørring Loennechen

Trondheim

\section{Når legen blir pasient}

Rygh 0.

\section{Undring fra rullestolen}

På jakt etter mestringskoden. 268 s, ill. Oslo: Kolofon forlag, 2009. Pris NOK 295 ISBN 978-82-300-0602-3

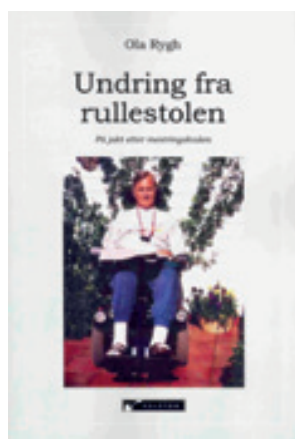

Kollega Ola Rygh var nettopp blitt pensjonist da han i 1995 styrtet på sykkelen, brakk nakken og ble rullestolavhengig tetraplegiker. Nå har han utgitt sine refleksjoner om det å være pasient i møtet med helsevesen og trygde-

system, i perspektivet fra et langt livs virke i norske sykehus. Men først og fremst er det en beretning om det å aldri gi opp, en hyllest til familien som kraftkilde og en kjærlighetserklæring til kona, som mer enn noen annen har gitt støtte og hjelp.

Vi følger forfatteren på veien gjennom sjokkfasen i starten, da det ble bråstopp for det fysisk aktive livet som han verdsatte så høyt, og videre gjennom en Pandoras kiste med besvær, komplikasjoner og møter med kolleger og institusjoner med varierende sjarm. Han er mange ganger langt nede, men hentes hver gang opp igjen av ukuelig livsvilje og støtte fra de nærmeste.

Boken er utgitt på Kolofon. Her gis forfatterne i liten grad forlagsfaglige råd $\mathrm{og}$ korrektur, og fremstillingen lider noe av det. Historien veksler mellom tanker rundt organiseringen av sykehusene før og nå, nyere biologiske erkjennelser og amatørfilosofiske refleksjoner. Dette har opplagt vært gode mestringsverktøy for forfatteren, men for leseren blir det springende og i blant litt banalt. Noe virker selvsagt for en leser fra helsevesenet, men samtidig faginternt for den som står utenfor. Bokens sterkeste side blir derfor selve beretningen. 